\title{
THE ILLINOIS CONSTITUTION AND HOME RULE FOR CHICAGO
}

\author{
BARNET HODES*
}

MONG the inequities that have arisen out of state government
under the Illinois Constitution of 1870 is the almost complete
lack of self-governing powers in the city of Chicago. It takes but a homely example to illustrate Chicago's lack of legal power to cope with its everyday problems.

Some years ago, the Law Department of the city of Chicago was requested to submit an opinion ${ }^{x}$ on the city's power to establish an automobile pound for motor vehicles which have been abandoned, parked illegally, or operated by intoxicated drivers. The closest specific grant of power that could be found was a statutory provision permitting the city to "prohibit the running at large of horses, asses, mules, cattle, swine, sheep, goats, geese, and dogs. . ..."

A marked lag has developed between the requirements of an efficiently functioning municipal government and the existing municipal law. The city of Chicago has been compelled to engage in endless struggles to secure enabling legislation from the state. Protracted and costly litigation has been necessary to keep grants once obtained. All this symbolizes, in a manner with which every city official has become only too familiar, the complete break between the real problems which confront city dwellers today and the political-legal mythology within which municipal government must function.

In spite of the concentration of sovereign power in the states and the widespread denial of self-government to the cities, the fact is that 56 out of every 100 Americans now live in cities of 2,500 population or more. More than 84 per cent of these city dwellers-or nearly half of our total population-live in metropolitan areas, that is, in cities of at least 50,000 inhabitants and their suburbs. In these metropolitan areas are located the great industrial plants and commercial enterprises which have made our civilization the most productive and powerful in human annals. Urban dwellers produce approximately 73 per cent of the nation's annual income

* Member of the Illinois Bar; formerly Corporation Counsel of the city of Chicago and member of the Illinois State Tax Commission.

I I8 Op. of Corp. Coun. 412, No. 75II (1929-35); ibid., at 668, No. 7244 .

${ }^{2}$ Ill. Rev. Stat. (I945) c. 24, § 23-85. 
and pay more than 90 per cent of all taxes collected by the federal, state, and local governments combined.

If the cities are so populous and powerful economically, how does it happen that they are so impotent legally? The answer is simply that rural interests have managed to retain control of our state legislatures by a refusal to redistrict the states as provided by their state constitutions and by the use of various gerrymandering techniques of districting the states to their advantage. If there is any large city or metropolitan area which is permitted to elect its fair share of state legislators, it is unknown to this writer. ${ }^{3}$

Agriculturally interested minorities dominate our state legislatures, because they dominated them when our state governments were first established and have since refused to relinquish their control. When our federal government became a going concern in 1789 , nearly 95 per cent of the population lived on farms or in rural communities. The largest city in the thirteen original states was Philadelphia with a population of 28,522 . The founding fathers, therefore, had reason to believe they could safely entrust the people's rights to the sovereign states which were dominated by agricultural interests. Even Tocqueville in his famous description of Democracy in America ${ }^{4}$ neglected to describe our city governments because he regarded our cities as complete departures from the American social norm. ${ }^{5}$

Consequently, the development of the modern city has not been coupled with a corresponding development of municipal legal powers. Our cities enjoy only such powers as the states which create them choose to confer upon them. This anomalous situation is based on concepts of government

${ }^{3}$ Cook County, which corresponds roughly with metropolitan Chicago, has more than half of the population of the state. Yet it has been permitted to elect only 57 of the 153 members of the lower house and 19 of the 50 state senators. Even the new redistricting act fails to give Cook and Lake Counties adequate representation in the state legislature. New York City, with 60 per cent of the state's population, is apportioned only 62 of the 150 assembly members and 23 of the 5 I state senators. Philadelphia, Pittsburgh, Los Angeles, St. Louis, Cleveland, and Detroit are further notorious examples of partial disfranchisement by the rural-controlled states.

4 Tooke, Progress of Local Government, 1836-1936 (1937).

5 Tocqueville and the founding fathers could afford to ignore the cities because only 200,000 of the then 3,929,214 American people lived in them. There were, in fact, no cities in the modern sense, and urban problems existed only in the speculations of philosophers like Thomas Jefferson who feared that cities might eventually develop as a threat to democratic government. In one sense, Jefferson's worst fears were realized; for metropolitan New York has the largest urban population in the world- $11,690,5$ 10- or nearly three times the population of the entire United States at the time the Constitution was adopted. In another sense, Jefferson's fears were quite misplaced, for the gravest assault on democratic government today comes not from the cities, but is leveled by the country folk on the cities in refusing to permit representation on the basis of population as guaranteed by both federal and state constitutions. 
which hark back to our agricultural forebears and are embalmed with time-defying permanence in our federal and state constitutions. No city government, therefore, can hold rentals or prices down one mill without a specific grant of authority from the state. And what is true of rent control is true of nearly every other function of local government from operating a municipal airport to running a municipal zoo.

Out of the hundreds of cases to which reference may be made, only a few more examples of the social and political schizophrenia which splits the city from the legal power it needs to function effectively in our atomic age need be cited.

As a step toward clearing its blighted areas, Chicago, like other American cities in twenty-three different states, established a local commission under authority of the state neighborhood redevelopment act. However, the Illinois state legislature refused to permit insurance companies to acquire capital stock in redevelopment corporations or to permit tax exemptions or tax reductions, thus rendering this type of investment so unattractive to private capital as to render the act quite unworkable. ${ }^{6}$

In this instance, no lack of technical knowledge or financial ability was involved; for the Illinois General Assembly had before it the example of the New York State Development Act, which grants partial exemption to developers and permits investment and stock control by insurance companies. As a result, ro,000 dwelling units were reported under construction in New York City in 1946 under the Neighborhood Redevelopment Act, in contrast to none in Chicago. Other successful housing developments whose examples failed to influence the Illinois state legislators are under way in Los Angeles and San Francisco. Chicago's lack of home rule powers and the necessary cooperation of its parent state thus automatically foredoom to failure any practical attempt to come to grips with the housing problem.

The city of Chicago also finds itself in a grave financial dilemma. Yet Chicago's real estate property tax is disproportionately high, because the city is still dependent for the bulk of its revenue on this antiquated tax, supplemented by the inequitable, hard-to-administer personal property tax and various license and permit fees. Recently, it is true, the city was voted authority to levy a local sales tax. The fact, however, that the State of Mllinois has practically pre-empted this field of taxation by its 2 per cent retailers' occupational tax and that any additional sales tax would require approval by public referendum leaves this measure obviously nothing but a political sham.

Other American cities have been able to solve their financial dilemmas

'See Chicago's Law Year 20-I (1946); also Chicago's Law Year 2I-2 (1945). 
by means of local sales, income, and payroll taxes, by taxes on cigarettes, tobacco, consumers' utility and water bills, and by new or increased license fees for operating amusement enterprises, taxicabs, and other types of businesses. However, the archaic revenue section of our state constitution plus the hidebound resistance of the state legislature toward giving Chicago home-rule revenue powers or sharing with it state-collected taxes leaves the city completely helpless to meet a potential deficit for 1947 of some $\$ 9, \infty 00, \infty 00 .^{7}$

In I 946 the American Municipal Association listed forty-three states as sharing state-collected taxes with their cities. The only tax thus shared by the State of Illinois is one-third of the motor fuel tax, or about $\$ 6, \infty 00,000$ a year. New York's Moore plan, by contrast, provided for a return to the cities in 1946 of more than $\$ 87,000,000$ in state-collected taxes as well as other forms of local assistance, bringing the total of local state-aid to $\$ 307,000,000$.

Chicago's complete legal impotence and its corresponding dependence on Springfield for enabling legislation results in the needless expenditure of a great deal of the city government's effort in wheedling, threatening, bargaining, and other political maneuvering. Mayor Kennelly's failure to induce Governor Green to permit the state legislature to share a twelfth of state-collected taxes with Chicago shows the futility of attempting to pit moral pressure, statistics, and logic against the cruder form of politics in Illinois today.

Furthermore, although city-dwellers are called upon to pay $9 \circ$ per cent of all federal and state taxes, no state legislature has so far been willing to leave entirely up to their judgment just how these taxes are to be assessed and levied. In Illinois, as in most other states, the legislature demands that the vassal cities derive the bulk of their local revenue from real property taxes. Usually this is augmented by taxes on personal property. Both these archaic methods of raising revenue are dear to the hearts of rural legislators. Both had their origin in colonial days, when practically everyone lived on a farm. In 1776 a citizen's wealth consisted mainly of land, farm buildings, and livestock. At that time the value of one's tangible property was a fair measure of one's wealth and ability to pay. The property tax had the added advantage that one could scarcely hide a farm or herd of cattle from the tax assessor. Today, when most city wealth is represented in stocks, bonds, and other intangibles-safely tucked away in bank vaults-these taxes are both unfair and difficult to collect. The states' in-

TStudies conducted by the Research Division of the Law Department indicate that Chicago's per capita municipal expenditures are among the lowest of any large city in the United States. 
sistence that cities employ property taxes has loaded urban real estate with such a crushing tax burden that millions of property owners have moved into the suburbs, selling their city buildings or permitting them to deteriorate into slums.

Not content with limiting cities to the archaic, unjust property tax for the bulk of their revenues, the state joins the federal government in highhandedly exempting extensive classes of property from local taxation because of their religious, educational, charitable, or governmental character.

State laws tell the cities not only how to raise their own revenue but how to spend it. To operate its own traction system, for instance, took years of political campaigning on the part of the city government merely to acquire the requisite authority from the state of Illinois. No matter what the emergency, the city of Chicago can make no expenditure not provided for in its annual appropriation bill. This last is a complicated budget, setting up separate funds for specific purposes in accordance with state laws. It is required by the state so that, even in spending its own money for state-approved purposes, the city may not transfer funds or deviate from the maximum sums or percentages fixed by the state for each local function.

Before any American municipality can issue a single bond, it must first secure permission from the state. Usually, then, it must secure approval of the bond issue by popular referendum. If a taxpayer chooses to test the "constitutionality" of the bond issue, the municipality must engage in a long and costly lawsuit to prove that the money will be used for legitimate local purposes.

A drastic revision of our archaic taxing laws would require the adoption of a new state constitution or extensive amendment of the present Revenue Article. The statutory provision that only one amendment to the constitution may be voted on at a time and that it must receive a majority of all votes cast at the election makes the chance of amending our Revenue Article appear infinitesimal. Attempts to facilitate this amending process through the use of "party circles" on ballots and by adoption of a "gateway amendment" seem equally hopeless today. ${ }^{8}$

A corps of city legal experts is engaged in constant litigation to protect those meager powers the city manages to wrest from the state. To establish the constitutionality of the amendment to the Cities and Villages Act giving municipalities the power to condemn property for slum clearance purposes and to test the validity of an ordinance authorizing the

${ }^{8}$ Sears, Constitutional Revision and Party Circle Bills, $1_{4}$ Univ. Chi. L. Rev. 200 (r947). 
issuance of $\$ 5,000,000$ in slum clearance bonds, it was necessary for the Law Department to secure a favorable ruling from the State Supreme Court through quo warranto proceedings. ${ }^{9}$ The city's power to license homes for the aged also had to be defended in prolonged litigation. In Father Basil's Lodge, Inc. v. Chicago, ${ }^{\text {10 }}$ the State Supreme Court ultimately held that the ordinances involved were health and safety regulations and, therefore, constituted police regulations which are within the power of the city to enact and enforce under Article 23 of the Revised Cities and Villages Act. Such proceedings are costly, lengthy, and prejudicial to innovation of any kind. Yet they are a necessary, routine activity of Chicago's Law Department.

Although in the above two instances the city was victorious, in other cases it is only too evident that while the city council or state legislature may propose, the state courts will dispose. In the case of Chicago v. Stone, ${ }^{\mathrm{Ix}}$ a city court had fined a storekeeper $\$$ I00.00 for purchasing a trumpet from a minor without consent of the minor's parents or guardian, which action constituted a violation of the Municipal Code. On appeal, however, the appellate court ruled that the city of Chicago lacked the power to adopt the ordinance under which the defendant was convicted. The court held that under Section 23-94 of the Revised Cities and Villages Act, the city was authorized only to issue licenses and regulate secondhand stores doing business similar to a "dealer in junk and rags." The defendant's store did not come within this precise category.

On such a comparatively simple matter as licensing juke boxes, the city had to enact a new ordinance, reducing the annual license fee from $\$ 50.00$ to $\$ 25.00$, because the original ordinance was held invalid by the State Supreme Court on the ground that a $\$ 50.00$ fee was "exorbitant."

Even when the city has been permitted to set up an agency such as the Civil Service Commission, a state court verdict may neutralize the commission's power. For instance, when nine police captains were suspended in 1943 for alleged failure to suppress gambling in their districts, they took their case into the courts, with the result that the Superior Court, later upheld by the appellate court in People ex rel Cartan v. Gregory, ${ }^{13}$ entered judgment quashing the record of the Civil Service Commission.

9 The People ex rel. Tuohy v. City of Chicago, 394 Ill. 477, 68 N.E. 2d 76I (r946).

${ }^{10} 393$ Ill. 246,65 N.E. $2 d 805$ (1946).

${ }^{11} 328$ Ill. App. 345, 66 N.E. 2d 100 (1946).

22 Lamere v. City of Chicago, 39 I Ill. $55^{2}, 63$ N.E. $2 d 863$ (r945); City of Chicago v. Kay, 282 IIl. App. 604 (r935).

${ }_{33} 329$ Ill. App. 307, 68 N.E. 2d 193 (I946), noted in I4 Univ. Chi. L. Rev. 270 (I947). 
Every Corporation Counsel of the city of Chicago soon learns that no city service may be performed by the city without the prior consent of the state. Such diverse and special problems as the regulation of toy guns, punishment for deceptive advertising, signatures on birth certificates, and streetcar facilities on certain city thoroughfares-all these purely local matters are determined by the state. ${ }^{\mathrm{I4}}$

Chicago is also a legal infant in the field of police powers. When a drivers' license law to compel examination of drivers was passed by the Chicago City Council in I904, it was declared void by our state courts for lack of authority. ${ }^{\text {Is }}$ Periodic testing by the city of auto brakes, lights, and other equipment was suggested in I93r, but could not be imposed until a state statute had been enacted in $1935 .{ }^{16}$ Even the type of automobile headlights permitted in Chicago could not be determined by the city except in accordance with rules established by a department of the state of Tllinois. ${ }^{17}$ Nor can the city inspect the automobiles of nonresidents, including suburbanites who use Chicago streets. ${ }^{18} \mathrm{~A}$ state law exempts trucks from periodic inspection of mechanical equipment, thus hindering the city from undertaking any comprehensive regulation of commercial vehicles. The City Council lacks power to determine speed limits on city streets or even the prima facie speed in alleys. ${ }^{29}$ When the city requested the passage of a law providing for the use of distinctive letters on license plates to designate residence in different sections of the state, the state legislature refused to adopt it..20 When the city sought to impound the cars of intoxicated drivers, it found it was powerless to do so because this would constitute a punishment not specified by state law..$^{25}$

Perhaps the prize instance of municipal impotence to come to my attention as Corporation Counsel was the effort of the city's Chief Electrical Inspector to stop the sale of an electrical device presenting a life hazard.

This device was an electrical mouse trap which electrocutes the mouse, then throws the.body clear of the trap. Despite the hazard to life involved in the use of this trap, the Law Department had to rule that the city had been given no express authority from the state to license the sale of elec-

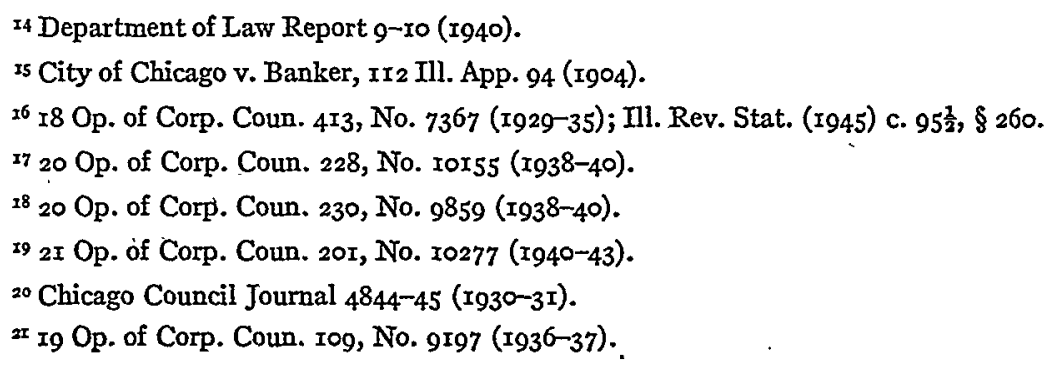


trical appliances. The Chief Inspector was within his rights in expressing his views concerning the appliance to the manufacturers, the vendor, and the public. But he could take no positive action to prevent human injury.22

Chicago's ability to benefit from the federal aid program for municipal airports and hospitals also is dependent purely on the future cooperation of the state of Illinois. The federal government's program provides for allocation of $\$ 75,000,000$ a year for five years to meet one-third the cost of constructing state and local public and non-profit hospitals. However, no federal aid may be extended to any municipality without approval by both the Public Health Service and a special state agency. Applications for federal assistance may be submitted by municipalities if not prevented by state law. ${ }^{23} \mathrm{Had}$ the federal and state governments granted our cities sufficient control over their own revenues, the cities could have solved their own problems without the roundabout method of "federal aid." The fact is that during the depression, as in normal times, the cities are milked by both federal and state governments, supplying the bulk of cash and wealth needed to support our complicated federal-state structure.

During the war, the legal inability of our cities to defend themselves or to take emergency action without first winning appropriate permission from the state, frightened not only responsible local officials but top executives of our federal government responsible for the nation's defense. By a brilliant piece of legal obfuscation, the Office of Civilian Defense was allowed to establish both New York and metropolitan Chicago as "states." Had they remained in their ordinary city status, the hostility, jealousy, delay, and red tape involved in dealing through their state governments would have rendered them as effective in an air raid or invasion as the Ladies Sodality in a like emergency.

During the war, the Chicago city administration foresightedly laid plans for extensive postwar reforms, including public ownership of its traction system, redevelopment of its blighted areas, the establishment of a municipal port authority modeled after that of New York City, and amendment of the Revenue Article. In order to secure the necessary authority from the state legislature, the Democratic party leader traveled to the state capital and reached-as he thought-an agreement with the head of the Republican state party.

However, this temporary political coalition was attacked with such bitterness by party die-hards that both the municipal port authority and the tax reform measures were voted down. As a consequence, Chicago suffered a major defeat in its attempt to deal intelligently with two of its

${ }^{22}$ Chicago's Law Year 56-7 (1946). ${ }^{23}$ Chicago's Law Year I7 (1946). 
biggest postwar problems. No Illinois community outside Chicago would have been affected one way or the other by how Chicago proposed to operate its port facilities or finance its own municipal operations. But because of a hostility to large cities which has its counterpart in every state legislature in the land, not only must Chicago struggle along with its present inadequate terminal facilities, but it faces a financial crisis.

Without independent political power, the financial and administrative outlook of our metropolitan cities, particularly of Chicago, is bound to become more and more desperate. As one who has been intimately concerned with municipal activities, I have reluctantly come to the conclusion that nothing short of drastic political action can wrest this power from our states. For that reason it has been said by municipal authorities that our best hope lies in strengthening the urban-federal relations begun in the form of federal grants-in-aid during the depression and strengthened during the war. This new partnership, it is urged, between Washington and the home town has already brought federal post-war aid to our cities for public housing, municipal airports, public hospitals, arterial highways, and city planning. Against the extension of this suggested partnership, a bitter rear-action fight by our states can be foreseen-particularly Illinois - to preserve every bit of their ancient rights and prerogatives. A municipal rebellion to counteract this opposition has been called for by some municipal experts. A vital objective of this struggle should be to establish urban autonomy within every state in the union or to establish our metropolitan areas as separate, independent, sovereign citystates.

Our cities need independent power. They need a position in our federal structure other than that of mere creature of the state. As a start-and only a start - they need a Secretary of Urban Affairs in the President's cabinet, with a streamlined Department of Urban Affairs to deal with urban problems and to coordinate the operations in metropolitan areas of our urban and federal governments. They need expert counsel, as well as legal authority, to reorganize, expand, and cooperate with other local governments to meet changing urban conditions. Eventually they need an amendment to our Constitution which will give them sovereignty in the whole field of metropolitan affairs comparable to that now reserved to our states.

Granted such a municipal bill of rights, American cities could use their economic wealth and power, their technical and cultural resources, to solve not only their own pressing problems but to help rural America achieve a better and more prosperous life. 